\title{
Experimental Hydrocephalus Pre-meeting 24th June 2009 Hazel Jones
}

Address: King's College London, School of Biomedical and Health Sciences, London, SE1 1UL, UK

Email: Hazel Jones - srhsb@btinternet.com

from 53rd Annual Meeting of the Society for Research into Hydrocephalus and Spina Bifida Belfast, UK. 24-27 June 2009

Published: 27 November 2009

Cerebrospinal Fluid Research 2009, 6(Suppl 2):S48 doi:10.1186/1743-8454-6-S2-S48

This article is available from: http://www.cerebrospinalfluidresearch.com/content/6/S2/S48

(c) 2009 Jones; licensee BioMed Central Ltd.

This was the $9^{\text {th }}$ session on animal hydrocephalus held since they were initiated in Atlanta, USA in 2000. The aim has been to give researchers who are presenting animal studies at the main meeting, the opportunity to present their work in an informal atmosphere with time for feedback and useful discussion from the audience which usually amounts to 20 - 40 people. This year the first talk was from Pat McAllister (University of Utah) on "CSF and Capillary Pulsatility in Hydrocephalus" in which he described some MRI experiments to measure the CSF stroke volume in the aqueduct of hydrocephalic rats using a 9.4 Tesla magnet. He went on to report measurements of the capillary pulse index in normal and hydrocephalic rats, using a 2-photon laser scanning microscope through a cranial window with promising results. The second talk was by Dorte Clemmensen, Neurosurgery, Aarhus University Hospital, on "Experimental Tethered Cord - a New Model". Tethered cord is a big problem in children with myelomeningocele and this group has been working to produce a pig model for future study. Using kaolin injections into the spinal cord they have been following the effects with MRI and are on the verge of success. The third talk was by Agustin Castaneyra-Perdomo, Universidad de La Laguna, Tenerife, on "Arterial Hypertension Effects on Choroid Plexus brain barriers". He described experiments to identify CSF and choroid plexus changes in the spontaneously hypertensive rat (SRH). Some proteins, $\mathrm{S} 100 \beta$, transthyretin and $\alpha 1$ antitrypsin were increased in hydrocephalus but many others were decreased. He suggested that the proteins behave similarly to Alzheimer's disease markers and that the SHR rat has disturbances of the blood brain and blood CSF barriers.
After a coffee break, Conrad Johanson, Brown University, spoke on "Molecular, Cognitive and Epigenetic Profiling for Aging Models: Implications for Hydrocephalus and Neurodegeneration". He explored the idea that changes in the CSF with aging may threaten ongoing neuroregeneration in the subventricular zone and dentate gyrus, particularly in relation to changes in $A \beta$ peptide and its transporters. Using 3 month versus 30 month-old rats they showed that $\mathrm{A} \beta$, the transporter RAGE and the glial markers, GFAP and OX6 increased with age whereas BRDU, the marker for cell division decreased. Aging rats performed less well on the Morris water maze test. He argued that there is a case for early intervention to prevent the cascade leading to Alzheimer's disease. Pat McAllister gave the next talk entitled: "Neuroinflammation in Neonatal Hydrocephalus". In a rat model with communicating hydrocephalus induced by kaolin, inflammatory cytokines were found in the cerebral cortex only. Using a more extreme model of hydrocephalus by induction at 1-2 days, they studied gene expression in the cerebral cortex using micro arrays and unique probe sequences. They found that out of 41,012 sequences 1,824 were changed at least 1.5 fold. Further analysis identified specific gene categories and individual genes that were affected. This was followed by the last talk by Janet Miller, Central Michigan University, "In Hydrocephalus, do Protein Levels Correlate with Gene Expression?" Janet has followed up her previous study using the H-Tx rat with inherited hydrocephalus where a number of genes had been shown to be linked to hydrocephalus. She argued that a more direct and potentially useful approach would be to study protein expression and using blotting techniques investigated the protein products of the altered genes found in the expression study. Interestingly, the 
direction of protein expression was often either opposite to the gene expression or showed no change.

Overall, this proved to be a most interesting morning provoking much discussion and we hope useful feedback for the presenters.

Publish with Bio Med Central and every scientist can read your work free of charge

"BioMed Central will be the most significant development for disseminating the results of biomedical research in our lifetime. " Sir Paul Nurse, Cancer Research UK

Your research papers will be:

- available free of charge to the entire biomedical community

- peer reviewed and published immediately upon acceptance

- cited in PubMed and archived on PubMed Central

- yours - you keep the copyright

Submit your manuscript here:

http://www.biomedcentral.com/info/publishing_adv.asp 